\title{
Georges Vacher de Lapouge a sélections sociales
}

\author{
Milan Hrabovský \\ Bratislava Policy Institute, Klariská 14, 81103 Bratislava \\ Do redakce doručeno 9. čevna 2020; k publikaci přijato 20. října 2020
}

\section{GEORGES VACHER DE LAPOUGE AND SÉLECTIONS SOCIALES}

\begin{abstract}
The study argues against Vacher de Lamoure's misleading ranking among the "forerunners" of Nazi racism. Vacher de Lapouge was not a "forerunner" of Nazi racism, but he was one of the key representatives of French Social Darwinism. As part of his "social selectionism" aimed at "practical selection" (sterilization and eugenics) of the weaker and poorer, in his view, "inferior", "parasitic" members of society, he offered his vision of a "new society" to promote the reproduction of "superior" race in society. That is why we should be interested in the thinking of this "most important French social Darwinist": in the 21st century, there are "racial theories" that do not have to refer to or be based directly on Nazi racism, but that does not mean that there are no other forms of racism.
\end{abstract}

KEY WORDS Vacher de Lapouge; Social Darwinism; eugenics; racism; race; Nazism; Aryan

\begin{abstract}
ABSTRAKT Štúdia argumentuje proti zavádzajúcemu radeniu Vachera de Lapouge medzi „predchodcov“ nacistického rasizmu. Vacher de Lapouge nebol „predchodca“ nacistického rasizmu, ale patril medzi klúčových predstavitelov francúzskeho sociálneho darvinizmu. V rámci svojho „sociálneho selekcionizmu“ zameraného na „praktickú selekciu“ (sterilizáciu a eugeniku) slabších a chudobnejších, z jeho pohladu, „menejcenných“, „parazitujúcich“ členov spoločnosti, ponúkol svoju víziu „novej spoločnosti“, ktorá má podporovat reprodukciu „nadradenej rasy“ v spoločnosti. To je aj dôvod, prečo by nás malo zaujímat myslenie tohto „najdôležitejšieho francúzskeho sociálneho darvinistu“: v 21. storočí existujú „rasové teórie, ktoré sa nemusia odvolávat alebo vychádzat priamo z nacistického rasizmu, to ale neznamená, že tu neexistujú iné formy rasizmu.
\end{abstract}

KLÚČOVÉ SLOVÁ Vacher de Lapouge; sociálny darvinizmus; eugenika; rasizmus; rasa; nacizmus; Árijec

1.

Pierre-André Taguieff napísal, že v pomyselnej galérii „slávnych rasových teoretikov“ zaujíma Georges Vacher de Lapouge (1854-1936) druhé miesto medzi prvým Arthurom Gobineauom (1816-1882) a tretím Houstonom Stewart Chamberlainom (1855-1927). Táto „slávna trojica“ sa objavuje bok po boku v rôznych štúdiách, knihách, slovníkoch a encyklopédiách venovaných nacizmu a rasizmu, a to hlavne v podobe akýchsi "predchodcov“ nacistického rasizmu (Taguieff 2013, 1807). ${ }^{1}$ Dokonca môžem nájst' aj zavádzajú-

1 V tejto štúdii sa nebudeme zaoberat myslením Arthura Gobineaua ani Houstona Stewart Chamberlaina, sústredíme sa iba na myslenie jedného z týchto údajných „predchodcov“ nacistického rasizmu: Georgesa Vachera de Lapouge. ci konštrukt kauzálneho „rasistického retazca“ v zmysle, že Gobineau splodil Vachera de Lapouge, Vacher de Lapouge Chamberlaina a Chamberlain Hitlera (Hrabovský 2018, 187). ${ }^{2}$ Avšak, ak už chceme hovorit’ o „predchodcoch“ nacistického rasizmu, potom toto vágne označenie platí jedine $\mathrm{v}$ prípade H. S. Chamberlaina, jedného z mála autorov, ktorého Hitler spomenul v Mein Kampf (Hitler 1936, 296). Hned' na úvod preto učiňme krátku poznámku, ktorú $\mathrm{v}$ tejto štúdii neskôr rozvedieme, že Gobineau ani Vacher de Lapouge rozhodne nepatrili medzi „predchodcov“ nacistického rasizmu: Gobineau nemohol predpokladat aká hrozivá ideológia sa neskôr vytvorí vôkol pojmu rasa (Budil 2015, 556) a Vacher de La-

2 Vacher de Lapouge však Gobineaua nikdy nenavštívil a do roku 1894 sa v jeho štúdiách nevyskytovala žiadna zmienka o Gobineauovi (Bloch 1987, 747). 
pouge sa ešte počas svojho života jednoznačne ohradil voči tomu, aby bol spájaný s „germanizmom“ a považoval Hitlerove chápanie rasy za „zdeformované“ (Laborde 1933, 8). Lenže neskoršie reflexie nacizmu po skončení II. svetovej vojny, ktoré hladali zdroje nacistického rasizmu, prisúdili „vynález“ nadradenej árijskej rasy „diabolskému aristokratovi“ - ktorý si však svoj šlachtický titul uvádzal neoprávnene (Budil 2009, 130) - a vyhlásili Gobineaua za priam „najväčšieho rasového darebáka" v 19. storočí (Hutton 1999, 3). Odsudzovanie Gobineaua však zakrylo to, že presadenie sa nacistického rasizmu by nebolo možné bez „prepojenia“ niektorých politikov - hlásajúcich nacionalisticko-rasistický Weltanschauung, trvajúci na nevyhnutnosti spoločenského pokroku a revitalizácie spoločnosti, prostredníctvom odstránenia „rasovo neplodných zložiek“ (daného) národa - $s$ autoritou modernej vedy. Bez tohto prepojenia politiky, nacionalizmu a vedy by rasové klasifikácie nikdy nezískali svoj deštruktívny potenciál. Neustále spájanie rasových klasifikácií (takmer výhradne) s nacizmom, bráni v pochopení, že existujú aj „nenacistické“ rasové klasifikácie, ktoré s nacizmom nemali nič spoločné, no neskôr boli - po vytrhnutí z ich kontextu - využité pri budovaní nacistického rasizmu. Historik Claude-Olivier Doron píše o „histoire épistémologique“ (epistemologickej histórii) rozličných typov rasových klasifikácií. $\mathrm{V}$ tomto prípade nás zaujíma výskum historických významov slova rasa, kde význam slova rasa využitý $\mathrm{v}$ rasizme je iba jeden $\mathrm{z}$ množstva významov slova rasa, ktorý sa objavil v histórii západnej civilizácie (Doron 2018, 479). Je preto nevyhnutné rozlišovat medzi (1) skúmanie epistemologickej histórie konkrétnych významov slova rasa, ktoré boli (a sú) využívané vo vedeckom výskume a nevedú $\mathrm{k}$ budovaniu rasovej ideológie; (2) skúmanie epistemologickej histórie konkrétnych významov slova rasa, vôkol ktorých sa v 19. storočí vytvorila ucelená ideológia hierarchizácie ludských rás, odvolávajúca sa na vedu. Avšak táto ideológia nepožadovala násilné vraždenie celých rasových skupín, ale odvolávala sa na odmietanie charity a sociálnej pomoci až sterilizáciu a eugeniku "slabších“, „chudobnejších“, a teda „menejcenných“, a „parazitujúcich“ členov spoločnosti. Vo frankofónnom prostredí je takáto ideológia označovaná tažko preložitel’ným pojmom „racialism“ (Taguieff 1998, 12); (3) skúmanie epistemologickej histórie konkrétnych významov slova rasa, vôkol ktorých sa vytvorila ucelená ideológia hierarchizácie ludských rás, rovnako odvolávajúca sa na vedu, ale smerujúca $\mathrm{k}$ stotožneniu rasy s konkrétnym „etnikom“ („národom“), s cielom násilne segregovat', vylučovat a následne vyvraždit’ celé rasové („etnické“, „národné“) skupiny, považované za „nižšie“, „menejcenné“ rasy. Vo frankofónnom prostredí je takáto ideológia označovaná pojmom „racism“/ rasizmus (Taguieff 1998, 12).

Hannah Arendt preukázala, že tematizovanie rasových klasifikácií patrilo až do 20. storočia k bežnej a neproblematizovanej ideovej výbave takmer všetkých západných krajín. Rasové klasifikácie a $\mathrm{z}$ nich vychádzajúce "rasové teórie“, boli jedným z mnohých názorov, ktoré sa snažili o získanie širšieho uznania a neodporovali ani myšlienkam „sociálnej spravodlivosti“ (Arendt 1979, 158-161), a dokonca v spojení s eugenickým hnutím 19. a raného 20. storočia bolo úsilie o „zlepšenie rasy“ chápané ako prostriedok k dosiahnutiu "pokrokovejšej", „kvalitnejšej“ a „bohatšej“ spoločnosti. „Rasové teórie“ sa počas 19. storočia stali súčastou spoločenských projektov, túžiacich vytvorit’ spravodlivejšiu spoločnost', „královstvo pozemské“, „král'ovstvo“ pokroku, zlepšenia, rozvoja či revitalizácie spoločnosti. „Rasové teórie“ 19. storočia stáli na princípe biologického determinizmu, ktorý s pomocou eugeniky usiloval o vyselektovanie najlepších „dedičných kvalít“ v danej populácií. Obhajcovia týchto „rasových teóriii“ opakovane tvrdili, že demokracia a kultúra (ich čias) bola skazená a dekadentná, kritizovali skorumpovanost' elít, korupciu, klientelizmus a individualizmus, pričom hlásali potrebu vytvorenia „nového človeka“, a odstránenie „neplodných“ a „nižších“, a „parazitujúcich“ „zložiek“ spoločnosti (Drábik 2019, 357, 547, 553, 556): v jadre ich „rasových teórii“ bola myšlienka pokroku a revitalizácie spoločnosti, dokonca až pokroku a revitalizácie celej Európy.

2.

Gobineau ani Vacher de Lapouge síce neboli predchodcami nacistického rasizmu, avšak Vacher de Lapouge ponúkol svoju víziu „eugenického racializmu“ (Taguieff 1998, 17) s cielom vybudovat' „novú spoločnost“, zameranú na „praktickú selekciu“ slabších a chudobnejších, z jeho pohladu, „menejcenných“, „parazitujúcich“ členov spoločnosti, presadzoval „sexuálnu službu“ „blond’avých dolichocefálnych“ žien pre zvýšenie pôrodnosti „nadradenej rasy“, obhajoval sterilizáciu „neprispôsobivých“ a jeho víziu „praktickej selekcie“ môžeme objavit’ aj v „teóriách“ rasistov 21. storočia, ktorí odmietajú, aby boli spájaní s nacistickým rasizmom. To je aj dôvod, prečo by nás malo zaujímat myslenie „najdôležitejšieho francúzskeho sociálneho darvinistu“ (Béjin 1982, 324): „teórie“ rasistov 21. storočia sa nemusia odvolávat’ alebo vychádzat’ priamo $\mathrm{z}$ nacistického rasizmu, to ale neznamená, že tu neexistujú iné formy rasizmu.

Vacher de Lapouge zásadne spochybnil osvietenské ideály, založené na krestanskom univerzalizme a humanizme. Kritizoval vplyv krestanstva v spoločnosti, „masovost“" a priemernost' demokracie, ktorá, podla neho, prestala vytvárat' výnimočné individuality a produkovala vládu priemernosti a nevzdelanosti. No na rozdiel od niektorých nacistických „vedeckých“ autorít, ktoré spájali „nadradenú rasu“ s nemeckým národom, a ktoré si kládli za ciel novú „rekonštrukciu“ a „očistu“ nemeckého národa, prostredníctvom vraždenia celých „rasovo menejcenných skupín“, Vacher de Lapouge nikdy nevolal po masovom vraždení celých „rasových“ skupín, nespájal „nadradenú rasu“ s nejakým konkrétnym národom, antisemitizmus nebol súčastou jeho „rasového projektu“ a nikdy nezaložil nijaké „vedecké“ inštitúcie zaoberajúce sa „definovaním“ skupín („rás“), ktoré mali byt’ v mene „pokroku“ vyvraždené (Taguieff 2013, 1812-1813, 1822). 
3.

André Pichot upozornil, že mysleniu Vachera de Lapouge sa „historici rasizmu“ vyhýbajú a len zriedka ho citujú (Pichot $2000,60){ }^{3}$ Vacher de Lapouge, ako sme už uviedli, je radený $\mathrm{k}$ „predchodcovi“ nacistického rasizmu (Taguieff 2013, 1807), za „duchovného otca“ nacizmu, $\mathrm{k}$ autorom, ktorí mali „priamy vplyv na nacistickú doktrínu“ (Hecht 2000, 286). Jedným z príkladov z repertoáru týchto klišé môže byt poznámka Jennifer Hecht, že myšlienky Vachera de Lapouge sa vyznačovali „pesimistickým ateizmom“, ktorý hraničil so samovražedným nihilizmom" (Hecht 2000, 287). Ak by bol Vacher de Lapouge "pesimista“ a „nihilista“, prečo ale potom napísal svoje štúdie a knihy, v ktorých volal po „praktickej selekcii“ smerujúcej k zlepšeniu a ochrane „nadradenej rasy v spoločnosti“ a svoju "teóriu“ nazval v roku 1933, v rozhovore s novinárom z Le Temps, „novým náboženstvom humanity“? (Laborde 1933, 8). Už tento jeden príklad odhaluje neustále trvajúce nepochopenie myšlienok tých obhajcov rasovej ideológie, ktorí sa nepodielali na budovaní nacistického rasizmu. Vacher de Lapouge patril k tým obhajcom rasovej ideológie, ktorí neusilovali o „revitalizáciu“ a "progres" nejakého konkrétneho národa (alebo štátu), ale chápali sa ako „apoštoli“ novej humanity a snažili sa, aby sa $\mathrm{v}$ rámci celej Európy (a teda v každom národe) presadili, $\mathrm{z}$ ich pohladu, „nadradené“ a „kvalitné" rasové typy.

Zaradit preto Vachera de Lapouge medzi obhajcov nihilizmu, krutosti, nenávisti, amorálnosti a násilia, vnáša do výskumu problematiky rasy a rasovej ideológie moralizmus, ktorý ponúka skôr zavádzajúce metafory, než kritickú analýzu. Tak ako v prípade Gobineaua, aj v prípade Vachera de Lapouge platí, že bol rasistickým „teoretikom“, ale sotva „duchovným otcom nacizmu“. V roku 1933 uskutočnil Guy Laborde, novinár Le Temps, rozhovor s Vacherom de Lapouge. Na otázku, čo si myslí o tom, ako Adolf Hitler zavádza do života jeho myšlienky, odpovedal: „Pokial ide o árijskú rasu, deformoval ju osobitým spôsobom. Neurobil ostatne nič iné, než že nadviazal na tradíciu nemeckých učencov, ktorí prekrútili Gobineaua a mňa samotného" (Laborde 1933, 8). Vacher de Lapouge, na rozdiel od Hitlera, nevzýval na masové vraždenie „menejcenných" rás a jasne sa vymedzil proti tomu, aby bol spájaný s "germanizmom“ (Taguieff 2013, 1808).

Vacher de Lapouge sa vo svojich knihách striktne držal jeho duálneho chápania dvoch konkurujúcich si „lebečných skupín“ (rás) a zásadne odmietol, aby sa rasami nazývali národy. V roku 1915 uviedol Vacher de Lapouge $\mathrm{v}$ časopise Mercure de France, že viera $\mathrm{v}$ nadradenost nemeckého národa je zmrzačenie histórie a antropológie, ktoré vedie jedine $\mathrm{k}$ zistovaniu akéhosi mystického pôvodu. V roku 1935, niekolko mesiacov pred svojou smrtou, napísal svojmu žiakovi Du Pontovi ohladom Hitlera: „Budúcnost' povie, či strašidelná politika tohto

3 Napríklad: Hannah Arendtová sa vo svojej knihe The Origins of Totalitarianism myslením Vachera de Lapouge nezaoberala a iba raz uviedla jeho meno, aj to len v poznámke pod čiarou (Arendtová 1979, 179). velkého človeka nepovedie iba k príšernému zabijaniu a ku koncu najlepšich“" (Taguieff 2013, 1808, 1843) a nacionálny socializmus považoval za hnutie usilujúce o vojnu a za „nacionalistickú úchylku" od jeho myšlienky sociálneho selekcionizmu, za jej „odpudivú karikatúru“ (Taguieff 2000, 49).

\section{4.}

Linda L. Clark si všimla, že sociálny darvinizmus vo Francúzsku získal počas 19. storočia význam „brutálneho ekonomického boja o život", teda obhajoba ekonomiky laissez-faire sa stala vyjadrením „biologického boja o život“. Z tohto dôvodu sa myšlienky sociálneho darvinizmu neobjavili v prácach biológov, ale medzi intelektuálmi ako bola spisovatelka Clémence Royer alebo Vacher de Lapouge. V roku 1862, približne dvadsatpät rokov predtým než Vacher de Lapouge publikoval svoje knihy Les Sélections Sociale (1896) a L'Aryen: Son Rôle Social (1899), vyšiel francúzsky preklad $O$ pôvode druhov z pera prekladatelky a aristokratky Clémence-Auguste Royer. Podla Iva Budila jej predhovor k tejto knihe položil základy sociálneho darvinizmu vo Francúzsku. V tomto úvode Clémence-Auguste Royer ponúkla radikálne ateistický, liberálny, antiklerikálny a nerovnostársky výklad Darwinovej teórie. Podla nej táto teória rozbíja myšlienku univerzálnej rovnosti medzi ludmi a ukazuje cestu ako dosiahnut zvýšenie plodnosti „fyzicky nadradených“ členov spoločnosti. Clémence-Auguste Royer presadzovala rasovú hierarchiu, kde na vrchole stoja Árijci ako vrchol evolúcie. Odmietala sentimentalizmus a humanizmus vo vztahu k „nižším rasám“, ktoré považovala za „podradné plemená" bez nádeje a budúcnosti. Iba ich odstránením môže vzniknút spoločnost vitálna, spravodlivá a prosperujúca. Pod jej vplyvom sa, slovami Budila, „prírodovedecká teória zmenila na extrémistickú politickú ideológiu“, ponúkajúca revitalizačný program smerujúci $\mathrm{k}$ zrodu novej árijskej elity (Budil 2017, 13-20). Počas rokov 1881 až 1909 boli vo vplyvnom The Journal des Economistes publikované state spájajúce ekonomickú konkurenciu s ideou „struggle for life“ a autori $\mathrm{v}$ tomto periodiku premenili obhajobu ekonomiky laissez-faire na myšlienku o vrodenej nerovnosti rás a odmietali preto solidaritu, charitu a starostlivost o slabých a chudobných. V rámci francúzskej verzie sociálneho darvinizmus došlo na prepojenie medzi sociálnym statusom a rasou. A práve Vacher de Lapouge využil meranie lebečného indexu ako základ pre určenie sociálneho statusu, charakteru a morálky, čím podla neho preukázal súvislost medzi rasou a sociálnou triedou (Clark 1981, 1025-1044).

V roku 1886 vznáša Vacher de Lapouge slovo eugenika do francúzskeho jazyka (Taguieff 2018, 518). Eugeniku považoval za "novú vedu“ vychádzajúcu z genetiky, založenú Francisom Galtonom. V roku 1888 uviedol túto „novú vedu“ slovami: „Existujú rodiny $z$ degenerácie (...) Existujú rodiny kriminálnikov. $V$ iných pochádza talent $z$ ich pôvodu, rovnako ako zdravie, sila a krása (...) Títo pochádzajú z eugeniky a eugenika je úsmev dedičnosti a degenerácie je jej preklatie“ (Vacher de Lapouge 1888, 175-176.). U Vachera de Lapouge je euge- 
nika spojená s víziou obnovenia nadradenej sociálnej kasty, novej rasovej aristokracie, a je v radikálnom protiklade voči ideálom rovnostárskej demokracie a myšlienke práv jednotlivcov. Podla P.-A. Taguieffa môžeme preto zaradit' eugenické myšlienky Vachera de Lapouge do tradície západnej filozofie, ktorá začala v Platónovej Ústave: kontrolovaním reprodukcie „nižších sociálnych“ tried sa vytvorí priestor pre reprodukciu „vyšších sociálnych“ tried, a tým daný štát začne vo zvýšenej miere produkovat' talentovaných, kreatívnych a cnostných členov spoločnosti, čím dôjde $\mathrm{k}$ pokroku, rastu a blahobytu daného štátu (Taguieff 1991, 23-45).

\section{5.}

Vacher de Lapouge pochádzal zo starobylej aristokratickej rodiny, absolvoval Collège des Jésuites a fakultu práva a medicíny v Poitiers. Vacher de Lapouge bol mimoriadne vzdelaný: na École des hautes études v Paríži študoval asýrčinu, egyptológiu a hebrejčinu, neskôr absolvoval École d`anthropologie a na École des langues orientales sa zaoberal čínštinou a japončinou (Béjin 1982, 324-325). Vo svojich prednáškach o Paulovi Brocovi (1824-1880) a Clémence-Auguste Royer (1830-1902) sa stal prvým francúzskym autorom, rozširujúcim eugenické „teórie“, prepojené na árijskú ideológiu a lebečný index považoval za dôležitejší rasový znak než farbu pleti (Taguieff 1998, 92-93). V rokoch 1866-1893 sa stal univerzitným knihovníkom v Montpellier, kde prvýkrát predniesol cyklus prednášok o antropológii, antroposociológii a asyrológii, ktoré sa stali základom jeho známej knihy Árijec, jeho sociálna úloha (L’Aryen : Son Rôle Social, 1889). Medzi jeho žiakov patril aj mladý Paul Valéry, ktorý mu v roku 1891 pomáhal zhromaždit šeststo lebiek z jedného starého cintorína (Béjin 1982, 325). V roku 1890 založil Vacher de Lapouge v Montpellier pobočku Parti ouvrier, prvej marxistickej politickej strany vo Francúzsku a kvôli povesti radikálneho socialistu mu bolo v roku 1892 zrušené akademické miesto (Taguieff 2013, 1812; Budil 2015, 874-875). V rámci svojich prednášok vysvetloval konflikty rôznych sociálnych tried optikou „biológie“, čím môžeme v jeho myslení vidiet’ „extrémnu variantu revizionistického marxizmu“ (Budil 2013, 54) či „rasizmus lavice“ (Budil 2015, 788). Aristokrat a zároveň socialista a rasista? Tento rozpor sa vysvetluje odkazom na objavenie sa „novej lavice“, o ktorej sám Vacher de Lapouge napísal: „(...) M. Niceforo uvidel, a mal na to dobré dôvody, že otázka, ktorá si zaslúži preskúmanie znie (...) či sa pri dôkladnom výskume chudobných tried nedajú objavit' nejaké nové veci. Preto volá antropológiu chudobných tried anthroposociológiou (...)“ (Vacher de Lapouge 1909, 227-228) (Béjin 1982, 325). A chudobné triedy, podla Vachera de Lapouge, nehladajú vlastné pozdvihnutie ani vyššie vzdelanie, ale to, čo závidia nadradeným triedam, nie sú ich vlohy a nadania, ale iba ich ekonomické benefity. Toto stanovisko viedlo Vachera de Lapouge k záveru, že musí existovat' „nerovnost' od prírody“, tak vo fyzickom výzore, ako aj v mentalite a inteligencii, ktorú je potrebné „prakticky selektovat" $\mathrm{v}$ prospech nadradených tried, pretože len tieto usilujú o vlastné, a v tomto zmysle aj „civilizačno-kultúrne“, pozdvihnutie (Vacher de Lapouge 1909, XXI).

Objavenie sa tohto „zvláštneho mixu“ - spojenie „lavicového“, selekčného (eugenického) a „revitalizačného“ sociálneho darvinizmu vo Francúzsku - pripisuje André Béjin skutočnosti, že Darwin nenašiel vo Francúzsku podobne vzdelaného biológa ako bol Thomas Huxley (v Anglicku), ktorý by propagoval a obhajoval jeho myslenie a kritizoval jeho zavádzajúce interpretácie (Béjin 1982, 327). Druhým dôvodom objavenia sa tohto „Zvláštneho mixu“ bol záujem (a zároveň obava) rôznych francúzskych intelektuálov o otázky spojené s demografiou, predovšetkým problém tzv. „dépopulation“ (vyludňovania) Francúzska (Béjin 1982, 327). Samotný Vacher de Lapouge venoval v roku 1887 jednu štúdiu práve problému nízkej natality vo Francúzsku, ktorú, podla neho, kompenzuje príchod vel'kého počtu cudzincov. Problém dépopulation je spojený $\mathrm{z}$ výmenou nadradených rás [races supérieures] za menej schopné rasy. Vacher de Lapouge vypracoval rozdelenie francúzskych regiónov na imigrantské brachycefálne a pôvodné, autochtónne dolichocefálne populácie, pričom objavil vysokú plodnost' menej schopných brachycefálnych populácií, ktorých vysoká natalita pochádza $\mathrm{z}$ ich miešania sa $\mathrm{z}$ inými rasami, a tým, podla neho, postupne nahradia kvalitné dolichocefálne populácie, strážiace si svoju rasovú čistotu odmietaním miešat sa. A už dvanást̉ rokov pred publikovaním jeho najznámejšej knihy L’Aryen : Son Rôle Social tvrdil, že v celej Európe prebieha konflikt dolichocefálnych populácií s brachycefálnymi populáciami. Dôsledok je ten, že chudobné, menej schopné, pasívne, prevažne katolícke, nebojovné a v polnohospodárstve pracujúce brachycefálne populácie nahradzujú schopné, pôvodné, aktívne, talentované, prevažne protestantské, bojovné dolichocefálne populácie. Konflikt, ktorý prebieha medzi týmto dvoma typmi európskych populácií a zvyšujúca sa natalita brachycefálnych populácií - ktorá sa prejavuje morálnym, charakterným, spoločenským, a tým aj ekonomickým úpadkom - by sa mala podla Vachera de Lapouge riešit’ prostredníctvom „praktickej selekcie“ brachycefálnych populácií. Iba dôsledným aplikovaním „praktickej selekcie“ brachycefálnych populácií je možné zastavit', podla Vachera de Lapouge, všadeprítomný úpadok spoločnosti (Vacher de Lapouge 1887, 69-80).

6.

Jeho vízia praktickej selekcie vychádza z Darwinových myšlienok, ktoré však neboli podla neho správne pochopené. Skutočná podstata Darwinovej teórie nie je o pôvode druhov, ale o ich prežití, a z pohladu prežitia sa môže presadit aj morálne, sociálne a spoločensky podradná forma života. Preto si nevystačíme len s Darwinovu tézou o „prírodnej selekcii“, ale je potrebné pristúpit k plánovanej sociálnej selekcii [sélections sociales]. Sociálny selekcionizmus je doktrína, ktorá má korigovat' nepriaznivé dôsledky „prírodnej selekcie“ na spoločnost' a má aktívne napomôct' presadeniu sa nadradených dolicho- 
cefálnych rás. Vedu, zaoberajúcu sa touto sociálnou selekciou, nazval antroposociológia [anthroposociologie] a považoval sa za jej zakladatela (Béjin 1982, 328). Svoju vedu považoval za reakciu na, podla neho, v jeho čase prebiehajúcu dyseugeniku [dysgéniques], ktorá likviduje nadradené dolichocefálne rasy prostredníctvom vojny (zabíja najlepších), demokracie (podporuje priemerných), náboženstva (ktoré monogamiou zabraňuje lepším mat viac potomkov), charity (podporuje slabých), ekonomiky (plutokracia zabraňuje objaveniu sa intelektuálnej aristokracie) a profesionalizácie (najvzdelanejší majú najnižšiu pôrodnost') (Béjin 1982, 329-330).

Sociálny selekcionizmus sa podla Vachera de Lapouge podobá socializmu, ktorý koriguje ekonomické nedostatky politických systémov smerom $\mathrm{k}$ najlepšiemu ekonomickému usporiadaniu. Za príklad volí USA. Chváli Spojené štáty, že našli odvahu a prijali sumu legislatívnych opatrení, zabraňujúcich reprodukcii potomstva, považovaného za nežiadúce, a ako príklad uvádza zákony amerických štátov, ktoré zakázali manželstvá medzi epileptikmi, imbecilmi, slaboduchými, syfilitikmi, alkoholikmi či lud’mi s tuberkulózou (Vacher de Lapouge 1899, 504-505). Presvedčenie o existencii sociálneho konfliktu medzi podradnými brachycefálnymi populáciami (triedami) a nadradenými dolichocefálnymi populáciami (triedami), ktorý, ako uvedieme nižšie, prevedie Vacher de Lapouge do rasového slovníka, aplikoval aj na jeho pochopenie zlyhania ideálov Francúzskej revolúcie, pretože sa prehliadlo, že tu nešlo o „súboj ideí “ alebo o „súboj rás“. Francúzska revolúcia odhalila, že myšlienky bratstva a rovnosti všetkých ludí sú proti zákonom prírody; skutočným zákonom dejín je konflikt rás (Vacher de Lapouge 1899, VII). „Motorom“ dejín sa pre Vachera de Lapouge stal boj rás, v ktorom nezohráva individuálny človek žiadnu rolu. Rasu prirovnal ku knihe, kde indivíduum je iba písmenom v knihe rasy. Písmeno samotné nemá nijaký význam, ale kniha áno (Taguieff 2018, 317): „Jedinou nesmrtelnostou, o ktorú môže človek usilovat', nie je v oblasti teologických snov, ale tá, ktorá zabezpečuje odovzdanie svojej plazmy [plasma] budúcim generáciám. Každý z potomkov je súčastou seba samého, reprodukuje sa, prenáša a buduje nové organizmy" (Vacher de Lapouge, 1896, 190-191).

\section{7.}

Vacher de Lapouge rozdelil pomocou anatomických kritérií (korešpondujúce s morálnymi a psychologickými znakmi) populačné zloženie Európy do troch rás: Homo europæeus (rasa nordická, árijská, dolichocefálna, blond s modrými očami), Homo Alpinus (rasa rastom menšia, brachycefálna, hnedá) a Homo Contractus (rasa mediteránna, dolichocefálna, hnedá) (Béjin 1982, 329; Taguieff 1998, 123-124).

Vacher de Lapouge odmietol Gobineauov pesimistický pohlad na pokrok rás. A za nositela potenciálu nového sociálneho a kultúrneho rozmachu života európskych spoločností prehlásil jednu zo „zoologických vetiev“ európskych rasových typov, ktorý pomenoval Homo europeus. Túto jednu konkrétnu vetvu, ktorá sa podla neho vyznačuje dolichocefálnym (dlhým a úzkym) tvarom lebky a svetlou farbou pleti, pomenoval árijská. Označenie árijský volí Vacher de Lapouge z dôvodu, že pojem árijský všeobecne potvrdili filológovia. Súhlasí s pôvodom pojmu árijský (vypožičaným zo „svätých kníh Indie a Perzie“), ale nesúhlasí s pôvodom skupiny, ktorú pojem árijský popisuje. Nepovažuje za „štastnú myšlienku“, že sa snád všetci Európania odvolávajú na árijský pôvod, ale kladie dolichocefálnu rasu, árijskú rasu par excellence, a teda aj Árijskú civilizáciu do škandinávskeho regiónu, do nížin Severného a Baltického mora (Vacher de Lapouge 1899, 1-3, 10).

Najváženejšie odsúdenie ale vyslovuje Vacher de Lapouge proti pojmu árijskej rasy, ak sa pripisuje nejakému národnému či etnickému typu. Vacher de Lapouge svojim chápaním rás odmietol ( $v$ jeho dobe) názory xenofóbnych nacionalistov (Taguieff 2000, 15) a prehlásil, že slovo rasa vychádza zo zoologickej taxonómie a neoznačuje „národné rasy“, čo je myšlienka „úplne metafyzická“, a veda nikdy nehovorí o rase latinskej, rase francúzskej, rase germánskej, rase slovanskej, alebo rase židovskej. Pojem árijský preto nemôže byt’ pripísaný rase $\mathrm{v}$ národnom alebo etnickom význame. Jediné vhodné použitie pojmu árijská rasa, i ked’ stále do istej miery nepresné, je, ak ide o árijskú civilizáciu geografickú s jej zoologickým typom (definovaným výškou, farbou očí a vlasov a tvarom lebky) (Vacher de Lapouge 1899, 7-8, 345-346). Vacher de Lapouge kritizuje politikov a spisovatel'ov hovoriacich o „latinských rasách“ alebo o „slovanských rasách“. Rasy neexistujú v ich "národno-etnickom“ chápaní, ale iba v zoologickom význame (Vacher de Lapouge - Closson 1897, 58). Árijec je pre Vachera de Lapouge skôr akýsi anatomicko-charakterovo-psychologický typ, jednota vonkajších anatomických znakov (dolichocefálna lebka, úzka a dlhá tvár, biela farba pleti) a vnútorného charakteru (tvorivá, asertívna, bojovná, vitálna, morálna a nábožensky prevažne protestantská), ktorá putujúc dejinami buduje vel'ké a mocné civilizácie. Nadradenost Árijca neleží v jeho „etnicite“ alebo „národnosti“, ale v jeho nadradených anatomických znakoch a charakterových vlastnostiach.

Druhý európsky anatomicko-charakterovo-psychologický typ, úplne odlišný od Árijcov, sú rasy s brachycefálnou (krátkou a širokou) lebkou. Medzi brachycefálne rasy radí Vacher de Lapouge šest' rás. Homo hyperboreus (Laponci), Homo contractus, Homo Alpinus, Homo Dinaricus, Acrogonus a rasu Furtooz. Pôvod brachycefálnych rás nie je podla neho známy a prikláňa sa k hypotéze, že ide o evolučný proces, ktorý prebiehal na úkor dolichocefálnych árijských rás. Vacher de Lapouge sa domnieva, že tieto brachycefálne rasy sa na konci neolitu rozliali cez Belgicko, Anglicko, Taliansko, Polsko a Rusko a neskôr sa vmiešali medzi dolichocefálnych Árijcov. Brachycefálne rasy sa vyznačujú prevažne katolíckym náboženstvom, náchylnostou k zotročeniu, sú vynikajúci otroci každého politického systému, pretože tolerujú jeho chyby a zlyhania. Kým dolichocefálni Árijci pracujú intelektuálne, v písomníctve, vede, umení a riadení, brachycefálne rasy pracujú iba $\mathrm{v}$ najtažších manuálnych profesiách (Vacher de Lapouge 1899, 227, 14-16, 231-238, 398). Výsledné rasové zloženie Európy sa skladá z dvoch anatomicko-charakterovo- 
-psychologických („lebkových“) typov: a) dolichocefálny Árijec, nadradený rasový typ, prevažuje vo Velkej Británii, severnom Nemecku, Holandsku, Škandinávii a v Spojených štátoch a charakterizuje ho protestantizmus; b) dolichocefálna rasa, podradnejší rasový typ, obývajúci Francúzsko, Švajčiarsko, južné Nemecko, Rakúsko, Pol’sko, severné Taliansko, Balkán, Malú Áziu a Kaukaz a je prevažne katolícka (Vacher de Lapouge - Closson 1897, 59-60, 64).

Navzdory týmto jeho „lebečným“ definíciám rás je zrejmé, že fyzické znaky rás sú len „povrchové“ definície. Vnútorné vlastnosti, ktoré Vacher de Lapouge pripisuje rasám, odhalujú, že tu máme dočinenia skôr so sociálnymi triedami, pričom lebkovo-rasové kritériá: „(...) sú iba politické kritériá, ktoré sú s pomocou niektorých úvah o forme lebky a farbe chlpov prestrojené za kritériá rasové (...) politický diskurz jasne presvitá cez tieto biologické termíny" (Pichot 2000, 352-353). A už $\mathrm{v}$ tomto bode môžeme vidiet, ako sa neskorší nacistický rasizmus, ktorý spojil árijskú rasu s konkrétnym „etnickým pôvodom“ (germánsky), etnicitou (Germán) a jazykom (nemecký), zásadne odklonil od myšlienok Vachera de Lapouge.

\section{8.}

Podla Vachera de Lapouge sú najnebezpečnejšími konkurentmi dolichocefálnych Árijcov Židia. Avšak nie v zmysle (vtedajšieho) politického francúzskeho antisemitizmu, ktorý stotožňoval Ârijcov s Francúzmi. Vacher de Lapouge radil Francúzsko medzi krajiny s prevahou „menej kvalitných“ brachycefálnych rás, a práve brachycefálne rasy, podla neho, vyvolali Revolúciu a chopili sa vlády. Antisemiti sú brachycefálne „nižšie (sociálne) triedy“ a jediným cielom ich antisemitizmu je získat politickú a ekonomickú moc. Nebezpečenstvo Židov pochádza zo skutočnosti, že majú taktiež prevažne dolichocefálne lebky (nie však árijský pôvod), čím sa stávajú priamymi konkurentmi dolichocefálnych Árijcov v schopnosti „dobývat’ svet“, a to prostredníctvom vysokých intelektuálnych kvalít, vitálnym duchom rasy a efektívnom využívaní práce brachycefálnych „otrockých“ rás. Vacher de Lapouge ale nevolal po vraždení Židov, pretože podla neho sa Árijec nemusí obávat konkurencie Židov (Árijec je obdarený mocnejšími a silnejšími anatomicko-charakterovo-psychologickými vlastnostami než Židia), ale skôr si vyčká na to, že sa Židia zničia sami (Vacher de Lapouge 1899, 464-476).

Medzi neeurópske farebné rasy radí Vacher de Lapouge Homo asiaticus (japonské, čínske, arabské rasy) a Homo Afer (černochov). A opät', dolichocefálny Árijec sa týchto rás nemusí obávat', nakolko je im anatomicky, morálne aj charakterovo nadradený, skôr by sa mal obávat menejcenných brachycefálnych rás vo vlastných radoch. Ázijské a čierne rasy vynikajú v manuálnych pozíciách, a preto zo selekcionistického pohladu nepovažuje za vhodné, aby sa eliminovali farebné rasy. Namiesto toho presadzuje víziu budúcej duálnej spoločnosti, v ktorej „nadradené a kvalitné“ dolichocefálne árijské rasy budú vládnut a „podradné a nekvalitné" brachycefálne a farebné rasy budú vykonávat iba hrubú manuálnu prácu. Čo vyčítal Vacher de Lapouge Židom - využívanie práce brachycefálnych rás vo svoj prospech - je sociálna pozícia, ktorú pripisuje Árijcom. Závažným dôsledkom jeho duálnej „európskej“ rasovej schémy („kvalitné“ dolichocefálne rasy verzus „nekvalitné“ brachycefálne rasy), ktorú nacistickí rasoví „teoretici“ odmietli, bolo jeho tvrdenie, že nie každá biela dolichocefálna („európska“) rasa patrí zároveň $\mathrm{k}$ árijskej rase. Ak člen dolichocefálnej rasy nedokáže preukázat svoj pôvod, ktorý Vacher de Lapouge lokalizoval do nížin vôkol Severného a Baltického mora, potom má síce dolichocefálnu lebku, ale nemá árijský pôvod. Vacher de Lapouge upozorňoval, že je vel'kým omylom označovat akýkolvek európsky národ ako celok pojmom árijská rasa. Európske národy sú zmesou dolichocefálnych a brachycefálnych rás. Takže bariéry pre presadenie sa dolichocefálnych árijských rás nevyplývajú z evolúcie, ale z politických zriadení. Brachycefálne rasy s ich „otrockou psychológiou“ presadzujú myšlienky slobody, rovnosti, humanizmu a ludských práv, ktoré zabraňujú, aby sa v spoločnosti presadili dolichocefálne árijské rasy $\mathrm{s}$ ich odvahou, bojovnostou, asertivitou, vzdelaním, podnikavostou, inteligenciou - vlastnosti, ktoré učinili a vybudovali zo západnej civilizácie silnú, bohatú a vitálnu civilizáciu (Vacher de Lapouge 1899, 378-379, 404, 483-487).

9.

Dôvod, prečo Vacher de Lapouge odmietol krestanstvo, demokraciu, liberalizmus a humanizmus nebola jeho „nenávist“ voči týmto politickým ideám či jeho „nenávistný rasizmus“, ale jeho zhrozenie sa nad stavom spoločnosti. Vacher de Lapouge sa $v$ jednom nevydanom článku z roku 1928 stažoval, že demokracia, krestanstvo a myšlienky solidarity, humanizmu a rovnosti vytvorili, podla neho, prostredie, v ktorom sa rozbujnela „hrozivá korupcia vo všetkých triedach“, kde „všetko je na predaj, ženy, sudcovia, úradníci, parlament, duchovenstvo, vlády“ (Taguieff 2013, 1841). Demokracia a jej snaha vytvorit” „raj na zemi“ viedla k skorumpovanej spoločnosti, ktorá už nemá záujem o podporu talentovaných a inteligentných dolichocefálnych rás. Riešením, tvrdil Vacher de Lapouge, preto nemá byt nová snaha o pozdvihnutie chudobných tried, ale práve naopak, odstránenie sociálnej solidarity, pretože „zlepšenie más je utópia vychádzajúca $\mathrm{z}$ nesprávneho pochopenia myšlienky evolúcie“ (Taguieff 2013, 1816). Pre Vachera de Lapouge, jedine dolichocefálni Árijci vybudovali velké a mocné civilizácie, jedine táto rasová skupina bola tvorivá, vitálna a morálna, schopná odolat' vnútenému rozkladu a korupcii. Vacher de Lapouge bol pesimista pokial išlo o snahy demokratov a humanistov o pozdvihnutie chudobných tried, pretože tieto politiky nevedú $\mathrm{v}$ skutočnosti $\mathrm{k}$ ich pozdvihnutiu, ale k skorumpovaniu všetkých tried. Nebol však pesimista pokial' išlo o novú víziu - revitalizáciu spoločnosti, ktorá má cez „praktickú selekciu“ odstránit” „skazené a neschopné“ osoby a podporit tak rozmnožovanie dolichocefálnej elity (Laborde 1933, 8). Podla Vachera de Lapougeho je preto nevyhnutné postavit vedu proti rovnostárskej demokracii (Taguieff 1998, 123). Sociálny selekcionizmus bol pre Vachera de Lapouge 
jediným prostriedkom, pomocou ktorého je možné zabránit celkovému rozkladu spoločnosti. Vacher de Lapouge bol presvedčený, že ak nedôjde $\mathrm{k}$ uplatneniu jeho chápania sociálnej selekcie, v spoločnosti prepukne vraždený barbarizmus, takže európske spoločnosti majú na výber: riadená eugenika alebo masové vraždenie. (Taguieff 1998, 95). Toto presvedčenie ho motivovalo k jeho slávnemu "proroctvu“, ktoré vyslovil v roku 1887 a neskôr v roku 1899: „Konflikt rás práve začína $v$ národoch a medzi národmi, a možno sa pýtat, či myšlienky bratstva, rovnosti ludí nie sú proti zákonom prírody (...) Som presvedčený, že v budúcom storočí sa budú ludia podrezávat" po miliónoch pre jeden alebo dva stupne lebečného indexu. Tento znak, ktorý nahradí biblický šibolet a jazykovú príbuznost', bude slúžit na identifikáciu národnosti (...) a poslední sentimentalisti budú svedkami masového vraždenia ludi゙ (Vacher de Lapouge 1887, 150-151; Vacher de Lapouge 1899, VII; Taguieff 2013, 1815; Budil 2015, 876). Na základe tohto „proroctva", ktorého naplnenie je údajne možné vidiet’ v nacistickom rasizme, je Vacher de Lapouge považovaný za proroka podobného Nostradamovi (Taguieff 1998, 96). Vacher de Lapouge ale nenavrhol iné riešenie sociálnych problémov (jeho čias) a v duchu jeho „novej vízie spoločnosti“ volal iba po „selekcii“ (eugenike) „slabších“, „menejcenných“ a „chudobnejších“ členov spoločnosti. A sociálni darvinisti 21. storočia hladajúcich nejaké „riešenie“ sociálnych problémov“, (vedome alebo neuvedomele) rovnako ako Vacher de Lapouge tvrdia, že sociálne problémy danej spoločnosti nie je možné odstránit nejakou formou sociálnej pomoci, ale jedine eugenikou „zaostávajúcich“ členov spoločnosti. Vacher de Lapouge ponúkol dalším sociálnym darvinistom zavádzajúcu (a zvádzajúcu) metódu argumentácie: ak sa najprv sústredíme iba na kritiku údajného celkového zlyhanie demokracie, krestanstva, humanizmu, rovnosti, charity, solidarity a rôznych programov sociálnej pomoci, a poukážeme na zdanlivú neschopnost demokratických spoločností riešit sociálne problémy v spoločnosti, potom musíme - $s$ cielom „zachránit“ prosperitu, rast a blahobyt spoločnosti a „zabránit“ masovému vraždeniu - prijat jedine adresné eugenické opatrenia. Takáto „argumentácia“ umožňuje obhajcom selekcie a eugeniky stát "na strane anjelov“: už sa nevidia ako obhajcovia neprijatelných a nehumánnych „metód“, ale ako „apoštoli“ novej „revitalizácie“, „progresu“ a „blahobytu“ „ludského druhu“.

Z myšlienok Vachera de Lapouge ale nevyplýva volanie po genocídnom vraždení celých rasových skupín. Jeho vízia bola „skromnejšia“: zlepšenie ludského druhu kontrolou pôrodnosti „menejcenných zložiek“ spoločnosti. Jeho „eugenický projekt" odhaluje skôr neustále prepájanie pokroku, blahobytu a prosperity s kultom zdravia, večnej mladosti a s idolatriou „inteligencie“ a sily. Takže podla P.-A. Taguieffa skôr ako v nacistickom rasizme môžeme dnes vidiet' „realizáciu“ praktickej selekcie Vachera de Lapouge v snahách o „seba-zlepšenie ludského druhu“ - čo má daleko od presadzovania árijského rasizmu - v túžbach niektorých skupín vytvorit zo seba „novú biologicko-genetickú elitu“ cez metódy genetických terapií, klonovania, biotechnológií, až genetického „prerobenia“ ludských embryí (Taguieff 1998, 163; 2013, 1847).

\section{LITERATÚRA}

Arendt, Hannah (1979): The Origins of Totalitarianism. San Diego, New York, London: A Harvest Book, Harcourt Brace \& Company.

Béjin, André (1982): Le sang, le sens et le travail : Georges Vacher de Lapouge darwinista social fondateur de l'anthroposociologie. Cahiers Internationaux de Sociologie, (73), 323-343.

Bloch, Jean-Richard (1987): Une Correspondance inédite : Jean-Richard Bloch et Vacher de Lapouge. Revue d'Histoire littéraire de la France, 87(4), 744-752.

Budil, Ivo (2009): Jitro Árijců. Praha: Triton.

Budil, Ivo (2013): Úsvit rasismu. Praha: Triton.

Budil, Ivo (2015): Triumf rasismu. Praha: Triton.

Budil, Ivo (2017): Clémence-Auguste Royerová a vznik sociálního darwinismu. Anthropologia integra, 8(1), 13-20.

Chapoutot, Johann (2014): La loi du sang. Penser et agir en nazi. Paris: Editions Gallimard.

Clark, Linda, L. (1981): Social Darwinism in France. The Journal of Modern History, 53(1), 1025-1044.

Doron, Claude-Olivier (2018): Histoire épistémologique et histoire politique de la race. Archive de Philosophie, 3(81), 477-499.

Drábik, Jakub (2019): Fašizmus. Bratislava: Premedia.

Hecht, Jennifer (2000): Vacher de Lapouge and the Rise of Nazi Science. Journal of the History of Ideas, 61(2), 285-304.

Hitler, Adolf (1936): Mein Kampf. München: Zentralverlag der NSDAP.

Hrabovský, Milan (2018): Rasa: rasová klasifikácia ludí. Bratislava: Veda.

Hutton, Christopher (1999): Linguistics and the Third Reich. London and New York: Routledge.

Laborde, Guy (1933): Un maître français de Hitler : Vacher de Lapouge. Le Temps, (26408), 8

Pichot, André (2000): La société pure. De Darwin à Hitler. Paris: Champ essais.

Taguieff, Pierre-André (1991): L’introduction de l'eugénisme en France : du mot à l'idée. Mots, (26), 23-45.

Taguieff, Pierre-André (1998): La Couleur et le sang. Doctrines racistes à la française. Paris: Mille et une nuits.

Taguieff, Pierre-André (2000): Sélectionnisme et socialisme dans une perspective aryaniste : théories, visions et prévisions de Georges Vacher de Lapouge (1854-1936). Mil neuf cent, (18), 7-51.

Taguieff, Pierre-André (2013): Vacher de Lapouge Georges, 1854-1936. In Taguieff, Pierre-André, éd., Dictionnaire historique et critique du racisme. Paris: Presses Universitaires de France - PUF, 1807-1853.

Taguieff, Pierre-André (2018): La force du préjugé. Essai sur le racisme et ses doubles. Paris: Gallimard.

Vacher de Lapouge, Georges - Closson, Carlos, C (1897): The Fundamental Laws of Anthropo-sociology. Journal of Political Economy, Vol. 6(1), 54-92.

Vacher de Lapouge, Georges (1887): La dépopulation de la France. Revue d'anthropologie, 2(1), 69-80.

Vacher de Lapouge, Georges (1887): L'Anthropologie et la science politique. Revue d'anthropologie, (16), 136-518.

Vacher de Lapouge, Georges (1888): L'hérédité dans la science politique. Revue d'anthropologie, (15 mars 1888), 169-191.

Vacher de Lapouge, Georges (1896): Les Sélections sociales. (Cours libre de Science politique professé à l'Université de Montpellier 1888-1889). Paris: Albert Fontemoing,

Vacher de Lapouge, Georges (1899): L’Aryen : Son Rôle Social. Paris: Ancienne Librairie Thorin et Fils.

Vacher de Lapouge, Georges (1909): Race et milieu social. Essais d'Anthroposociologie. Paris: Marcel Rivière. 


\section{AUTOR}

Milan Hrabovský, PhD. (1978, Ružomberok, neskôr Lubochňa) vyštudoval na Univerzite J. A. Komenského v Bratislave filozofiu. Absolvoval pobyt v Bruseli a letnú školu na St. John's College v Oxforde. V roku 2011 publikoval svoju doktorskú prácu Rasová mytológia, prvú slovenskú monografiu o pojme rasa a v roku 2018 monografiu Rasa: rasová klasifikácia ludí (VEDA, 2018), ktorá získala prémiu Literárneho fondu za vedeckú a odbornú literatúru v kategórii spoločenské vedy za rok 2018. S profesorom Nižňanským je spoluautorom prvej slovenskej učebnice Rasizmus, antisemitizmus, holokaust (anticiganizmus) (2013). Je nositelom ocenení Ministra práce, sociálnych vecí a rodiny SR za prácu v oblasti migrácie a integrácie cudzincov (2012) a prezidenta Policajného zboru Slovenskej republiky za vypracovanie „Všeobecného manuálu pre otázky rasizmu, diskriminácie a xenofóbie“ (2007). Viac ako 15 rokov sa venuje problematike rasy a rasizmu a je autorom viacerých štúdií, v ktorých sa venuje predovšetkým problematike rasy. Žije v Senci a má jedno dieta.

Kontakt: milan.t.hrabovsky@gmail.com 